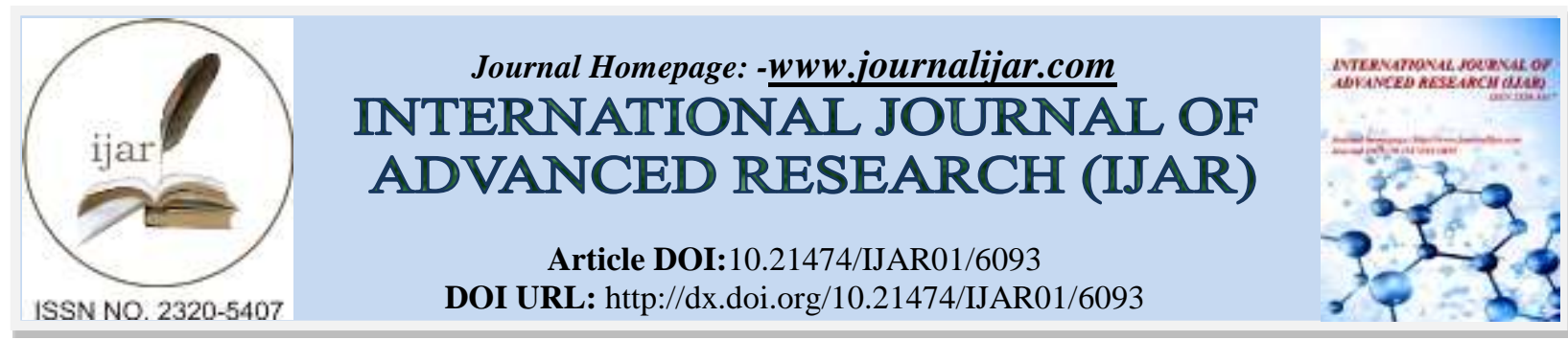

RESEARCH ARTICLE

\title{
EFFECT OF INORGANIC AND ORGANIC FERTILIZERS ON FRUIT QUALITY AND YIELD ATTRIBUTES IN GUAVA CV. SARDAR.
}

Harpinder Kaur ${ }^{1}$ and Gurpinder Kaur ${ }^{2}$.

1. Msc research student ${ }^{1}$ Department of Horticulture, Khalsa College, (GNDU) Amritsar-143001.

2. Assistant Professor ${ }^{2}$ Department of Horticulture, Khalsacollege, (GNDU) Amritsar-143001.

\section{Manuscript Info}

Manuscript History

Received: 18 October 2017

Final Accepted: 18 November 2017

Published: December 2017

Keywords:-

Guava, Inorganic and Organic fertilizers,

Fruit physical and biochemical parameters, Fruit yield.

\section{Abstract}

The present investigation entitled "Effect of inorganic and organic fertilizers on fruit quality and yield attributes in guava cv. Sardar” was carried out in a well maintained Guava orchard, Khalsa College, Amritsar during 2016-17. In the trial, 18 guava trees of cv. Sardar with uniform size and vigour were selected. The selected trees were fertilized with Recommended dose of fertilizers i.e. $600 \mathrm{~g}$ urea, $2000 \mathrm{~g}$ super phosphate and $1000 \mathrm{~g}$ muriate of potash, Vermicompost @ 16 kg/tree, Jeevamrit@10 litre/tree, Azotobacter and Azospirillum @ $100 \mathrm{~g} /$ tree. Fruits were analyzed for their physical and biochemical parameters at Horticulture laboratory of Department of Horticulture, Khalsa College. It was revealed from the study that trees fertilized with recommended dose of NPK yielded fruits with significant fruit length $(9.2 \mathrm{~cm})$, fruit breadth $(8.72 \mathrm{~cm})$, fruit weight $(222.43 \mathrm{~g})$ and also the fruits attained high organoleptic rating, excellent fruit colour and minimum fuit firmness $\left(2.93 \mathrm{~kg} / \mathrm{cm}^{2}\right)$. The fruit obtained from trees treated with recommended dose of inorganic fertilizers had maximum TSS $(12.19 \%)$, reducing sugars $(5.43 \%)$, total sugars $(7.97 \%)$, nonreducing sugars $(2.54 \%)$, ascorbic acid content $(203.91 \mathrm{mg} / 100 \mathrm{~g}$ of pulp) and minimum titratable acidity $(0.54 \%)$. Also, the guava trees under treatment $\mathrm{T}_{1}$ took minimum days (98.33) for fruit maturation and yielded maximum number of fruits (282.00) per tree with the fruit yield of $62.73 \mathrm{~kg}$. Hence, inorganic fertilizers were found to be the most efficacious in encouraging the quality and yield of Sardar guava fruits.

Copy Right, IJAR, 2017,. All rights reserved.

\section{Introduction:-}

Guava (Psidiumguajava L.) is one of the most important fruit crop of family Myrtaceae and also claimed to be the fourth most important tropical fruit crop in India after mango, banana and citrus (Duttaet al 2014). It has assumed significance owing to its hardy nature and prolific bearing even under marginal lands with little care and minimal inputs (Sahuet al 2014). It is often called as "poor man's apple or "Apple of Tropics" owing to its excellent taste, flavor, high nutritional value and wide adaptability at moderate price (Dhomane and Kadam 2013). It is commonly known for its food and nutritional value throughout the world (Kumar 2012). 
The dispensable use of chemical fertilizers has widened soil imbalance in terms of NPK ratio and overall decline in production capacity of soil (Chhonkar 2008). Integration of organic substrates with chemical fertilizers can have significant effect on the physical, microbiological and chemical properties of soil, which are responsible for supporting plant growth. Use of organic manures along with biofertilizers and crop residues is considered as a cheap source of available nutrient to plants which have beneficial effects on growth, yield and quality of various fruit crops (Katiyaret al 2012). Considering economy, energy and environment, it is imperative that plant nutrients should be used effectively by adopting proper nutrient management system to ensure high yield and to sustain the availability in soil at optimum level for getting higher yield and quality fruit production for which nutrient management is necessary (Yadav 1999). Scanty information is available on the effect of biofertilizers and organic manures along with the chemical fertilizers in guava, hence the present investigation entitled "Effect of inorganic and organic fertilizers on fruit quality and yield attributes in guava cv. Sardar" was planned to check out the nutritional schedule with a view to improve the quality and yield of guava fruits.

\section{Materials and Methods:-}

The present investigation entitled "Effect of inorganic and organic fertilizers on fruit quality and yield attributes in guava cv. Sardar" was carried out during 2016-17. The material used for the present experiment were Urea, Superphosphate, Muriate of Potash, Vermicompost, Jeevamrit, Azotobacter and Azospirillum. In the trail, seven year old guava tree having uniform vigour were selected for the study. The experiment was laid out in Randomized Block Design (RBD) with three replications. Various inorganic and organic fertilizers were applied alone consisting of total six treatments $\mathrm{T}_{1}$ RDF (600g Urea, 2000g SP, 1000g MOP), T Vermicompost (16 kg/tree), $\mathrm{T}_{3} \mathrm{Jeevamrit} \mathrm{(10}$ 1/tree), $\mathrm{T}_{4}$ Azotobacter (100g/tree), $\mathrm{T}_{5}$ Azospirillum $\left(100 \mathrm{~g} /\right.$ tree) and $\mathrm{T}_{6}$ Control.As per recommendation by PAU, Ludhiana (Anon 2015) half of inorganic fertilizers were applied in July and remaining half in September, Vermicompost in July, Biofertilizers: Azotobacterand Azospirillum were applied during second fortnight of August by mixing in soil. However, Jeevamrit was applied in five splits at the interval of 15 days. The observations on fruit length and breadth were measured with Vernier'sCalliper, fruit weight with electronic balance, fruit firmness with Penetrometer and organoleptic rating with panel of five judges as per Hedonic scales (1-9 points). TSS of guava fruits was determined by refractrometer. The chemical parameters like titratable acidity, total sugars, reducing sugars and ascorbic acid were measured as per standard procedures of AOAC (1990).

\section{Results and Discussion:-}

Maximum fruit length $(9.2 \mathrm{~cm})$ was recorded in the fruits harvested from plants treated with recommended dose of fertilizers $\left(T_{1}\right)$ and was found to be closely followed by treatment $T_{2}$ (vermicompost) with fruit length of $8.96 \mathrm{~cm}$. Both the above treatments were found to be significant over the rest of the treatments. However, the plants manured with Vermicompost $\left(\mathrm{T}_{2}\right)$ yielded fruit with fruit length of $8.96 \mathrm{~cm}$, which were found to be at par with the treatment $\mathrm{T}_{5}(8.41 \mathrm{~cm})$. Minimum fruit length $(6.93 \mathrm{~cm})$ was recorded under control.

Maximum fruit breadth $(8.72 \mathrm{~cm})$ was recorded in plants fertilized with recommended dose of fertilizer $\left(\mathrm{T}_{1}\right)$. The former treatments was found to be statistically at par with treatments $\mathrm{T}_{2}$ (Vermicompost), $\mathrm{T}_{5}$ (Azospirillum) and $\mathrm{T}_{4}$ (Azotobacter) with fruit breadth of $8.70,8.35$, and $8.34 \mathrm{~cm}$ respectively. Whereas minimum fruit breadth $(7.8 \mathrm{~cm})$ was recorded under $\mathrm{T}_{6}$ (control) which was closely followed by $\mathrm{T}_{3}$ (Jeevamrit) with fruit breadth of $7.94 \mathrm{~cm}$.

The increase in fruit size (length and breadth) might be due to the enhancement of vegetative growth with the application of inorganic fertilizers by which the rate of photosynthesis increased and ultimately the metabolic activities of plant get accelerated, thereby the fruit size improved affectively. Whereas, Vermicompost improves microbial distribution and moisture retention capacity in soil that results in greater enzymatic activities which improves the growth parameters which ultimately reflect in increased fruit size (Binepalet al 2013). The above findings are in accordance with the findings of Athaniet al (2007), Ram et al (2007) and Sharma et al (2014), Osman and EI- Rahman (2009) in guava, Verma and Chauhan (2013) in apple, Patel and Naik (2010) in Sapota.

Maximum fruit weight (222.43 g) was found in the plants under treatment $\mathrm{T}_{1}(\mathrm{RDF})$ which was statistically at par with treatments $\mathrm{T}_{5}$ (Azospirillum) and $\mathrm{T}_{2}$ (Vermicompost) with fruit weight of $220.22 \mathrm{~g}$ and $218.44 \mathrm{~g}$ respectively. However, the untreated plants yielded minimum weighed fruits $(204.66 \mathrm{~g})$. The increase in fruit weight due to inorganic fertilizers could be due to greater mobility of nutrients to the developing fruits. Whereas the increase in fruit weight by vermicompost might be due to the increase in enzymatic activities in plant metabolic processes which ultimately leads to increase in fruit weight. Similar results were reported by Athaniet al. (2007), Ram et al 
(2007) , Sharma et al (2014) in guava and Osman and EI- Rahman (2009), Verma and Chauhan (2013) in apple, Patel and Naik (2010) in Sapota and Lal and Sen (2001) in guava.

Minimum fruit firmness $\left(2.93 \mathrm{~kg} / \mathrm{cm}^{2}\right)$ was recorded in fruits obtained from plants supplied with recommended dose of fertilizers $\left(T_{1}\right)$. The above treatment $\left(T_{1}\right)$ was statistically at par with treatments $T_{2}, T_{5}$ and $T_{3}$ with fruit of 3.08, 3.16 and $3.19 \mathrm{~kg} / \mathrm{cm}^{2}$ respectively. The reduction in fruit firmness with the use of fertilizers might be due to intensive solubilization of pectin from cell wall to starch breakdown and reduction of turgor (Tucher 1993).Similar results were also found by Chatterjeeet al (2013) in tomato and Osman and EI- Rahman (2009) in guava.

Maximum points (9.00) were awarded to the fruits obtained from plants treated with treatment $T_{1}(R D F)$ and was closely followed by treatments $\mathrm{T}_{2}, \mathrm{~T}_{5}$ and $\mathrm{T}_{4}$ with organoleptic rating of $8.66,8.33$ and 8.00 respectively. While least organoleptic rating 7.33 under treatment $\mathrm{T}_{3}$ (Jeevamrit). It might be due to the fact that with the application of fertilizers the vegetative parameters improved significantly, which results in higher photosynthesis rate and better translocation of metabolites to the fruits which improves the quality of fruits (Naik and Haribabu 2007). Results of these findings are confined by Umar et al (2009) in strawberry, Binepalet al (2013) and Pathak and Ram (2004) in guava.

The best coloured (8.66 PY) guava fruits were obtained under treatment $\mathrm{T}_{1}(\mathrm{RDF})$ which was followed by treatments $T_{2}$ and $T_{5}$ respectively with pale yellow (8.33) and yellowish green (8.00) fruits. Least fruit colour development $(6.50 \mathrm{G})$ was noticed in plants under control and was found to be at par with treatments $\mathrm{T}_{3}(7.00 \mathrm{LG})$ and $\mathrm{T}_{4}$ (7.33 YG). Similar results were also found by Chatterjeeet al (2013) in tomato.

From the data it has been observed that minimum days (98.33) were taken by trees for maturation of fruits under treatment $T_{1}$ and found to be closely followed by treatment $T_{2}$ with maturation time of 99.33 days. However these treatments were found to be significant to all the other treatments, whereas the trees under control took maximum days i.e. 105.33 for fruit maturation. The present results are in line with the findings of Sandhu and Gill (2011) in cape gooseberry.

Significant TSS (12.19\%) was recorded in fruits produced from plants treated with recommended dose of fertilizers $\left(\mathrm{T}_{1}\right)$. The improvement in TSS by the application of recommended dose of NPK may be explained by the fact that phosphorous enters into the composition of phospholipids and nucleic acids, the latter combines with proteins and results in the formation of nucleo-proteins which are the important constituents of the nuclei of the cells. Potassium acts as a catalyst in the formation of more complex substances and in the acceleration of coenzymes are beneficial in the improvement of fruit quality and nitrogen enhances the uptake of phosphorous and potassium (Binepalet al 2013). The minimum TSS (8.80\%) was recorded undercontrol and found to be statistically at par with treatment $\mathrm{T}_{4}$ with TSS content of 9.14 per cent. Results of these findings were also confined by Umar et al (2009) in Strawberry, Athaniet al (2007), Ram et al (2007) and Sharma et al (2014), Sharma et al (2013) also reported in guava and Khehra and Bal (2016) in lemon.

Non significant effect on titratable acidity of guava fruits was noticed. Minimum acidic content $(0.54 \%)$ was recorded in the fruits picked from plants treated with $\mathrm{T}_{1}(\mathrm{RDF})$. NPK fertilization might helps in the uptake of other nutrients which helps in improving the fruit quality significantly (Sharma et al 2014). Similar observations have been reported by Khehra and Bal (2016) in lemon and Saravananet al (2013) in Phalsa. The plants under control yielded highly acidic fruits with titratable acidity of 0.63 per cent.

Maximum TSS: acid ratio (22.51) was recorded under treatment $\mathrm{T}_{1}(\mathrm{RDF})$ and was closely followed by treatment $\mathrm{T}_{2}$ (Vermicompost) with TSS: acid ratio of 19.8. However, both the former treatments were found to be significantly superior to rest of the treatments. Increase in TSS: acid ratio is caused by decrease in titratable acidity and increase in TSS contents of fruits which contributed of fruit flavor. Minimum TSS: acid ratio (13.96) was observed under control. These results are in accordance with the findings of Tassaret al (1989), Lal and Sen (2001) and Meenaet al (2005) in guava.

From the data, it has been observed that RDF improved the total sugars in fruits (7.97\%) and also found to be statistically at par with treatment $\mathrm{T}_{2}$ (Vermicompost) with total sugars of 7.63 per cent. Minimum total sugars (7.13\%) were registered in fruits obtained from trees under control. 
It was noted that trees under treatment $\mathrm{T}_{1}$ yielded fruits with maximum reducing sugars $(5.43 \%)$ and was also followed by treatments $\mathrm{T}_{2}, \mathrm{~T}_{3}$ and $\mathrm{T}_{5}$ in line with reducing sugars of 5.35, 5.23 and 5.28 respectively. Minimum reducing sugars $(4.74 \%)$ were observed in control.

Maximum non-reducing sugars $(2.54 \%)$ were recorded in the fruits harvested from plants treated with $\mathrm{T}_{1}(\mathrm{RDF})$ and minimum $(2.18 \%)$ were recorded under treatment $\mathrm{T}_{3}$ (Jeevamrit).

The increase in sugar content of fruits by the use of recommended dose of NPK fertilizers might be due to the enhancement in uptake of nutrients which lead to increased catalytic activities by which the complex substances (starch) degrade into simple sugars and thereby improve the fruit quality. The present results are in accordance with the findings of Duttaet al (2009), Binepalet al (2013) in guava and Butani and Chovatia (2014) in Banana.

Maximum ascorbic acid content $(203.91 \mathrm{mg} / 100 \mathrm{~g}$ pulp) was found in the fruits produced from plants treated with recommended dose of fertilizers $\left(\mathrm{T}_{1}\right)$. It was found to be at par with treatments with $\mathrm{T}_{2}\left(\right.$ Vermicompost) and $\mathrm{T}_{5}$ (Azospirillum) with ascorbic acid content of 200.41 and $198.33 \mathrm{mg} / 100 \mathrm{~g}$ pulp respectively. Minimum ascorbic acid ( $189.16 \mathrm{mg} / 100 \mathrm{~g}$ pulp) was recorded under control and was found to be at par with treatments $\mathrm{T}_{3}, \mathrm{~T}_{4}$ and $\mathrm{T}_{5}$ with ascorbic acid content of 189.58, 190.41 and $198.33 \mathrm{mg} / 100 \mathrm{~g}$ pulp respectively. Similar observations have also been reported by Duttaet al (2009) in guava and Khehra and Bal (2016) in lemon. Increase in nitrogen application has also been found to increase ascorbic acid content in Cape gooseberry (Ali et al 2003).

A perusal of data clearly indicates that significantly maximum number of fruits (282.00) was calculated in guava trees under treatment $\mathrm{T}_{1}$ (RDF) and was followed by treatment $\mathrm{T}_{2}$ with fruit number of 272.33. Significant maximum fruit yield $(62.73 \mathrm{~kg} /$ tree $)$ was recorded under treatment $\mathrm{T}_{1}$. Minimum fruit yield $(45.22 \mathrm{~kg} /$ tree $)$ was obtained under Control and was found to be at par with treatment $\mathrm{T}_{3}$ (Jeevamrit) with fruit yield of $47.66 \mathrm{~kg}$ per plant. Significant increase in fruit yield might be attributed to the increased fruit number per plant, fruit size and weight. Moreover, the NPK fertilization might accelerate the process of synthesis and accumulation of food materials, which promotes the hormonal activity and include their synthesis and it ultimately leads to increase in number of fruits and yield. The above findings are in accordance with Dwivedi (2012), Shuklaet al (2014), Meenaet al (2013) in Guava, Laxmiet al (2015) in tomato, Saravananet al (2013) in Phalsa and Butaniet al (2013) in Banana.

\section{Conclusion:-}

It is concluded from the present study that fruit quality parameters as well as yield per plant was improved with the use of recommended dose of fertilizers $\left(\mathrm{T}_{1}\right)$. Also the guava trees fertilized with recommended doses of NPK took minimum days for fruit maturation. However, the treatment $\mathrm{T}_{1}$ (RDF) was found to be statistically at par with the treatment $\mathrm{T}_{2}$ (Vermicompost) in improving the desired characters of guava fruits. But the input cost of vermicompost should be taken into consideration, it is advised that the RDF has to be used in proper manner to improve the physical, biochemical and yield parameters in guava cv. Sardar.

Table 1:- Effect of inorganic and organic fertilizers on physical parameters in guava cv. Sardar

\begin{tabular}{|c|c|c|c|c|c|c|c|c|c|}
\hline Treatments & $\begin{array}{c}\text { Fruit } \\
\text { length } \\
(\mathrm{cm})\end{array}$ & $\begin{array}{c}\text { Fruit } \\
\text { breadth } \\
(\mathrm{cm})\end{array}$ & $\begin{array}{c}\text { Fruit } \\
\text { weight } \\
(\mathrm{g})\end{array}$ & $\begin{array}{c}\text { Fruit } \\
\text { firmness }\end{array}$ & $\begin{array}{l}\text { Organoleptic } \\
\text { rating }\end{array}$ & $\begin{array}{l}\text { Fruit } \\
\text { colour }\end{array}$ & $\begin{array}{l}\text { Maturation } \\
\text { time (days) }\end{array}$ & $\begin{array}{l}\text { Number } \\
\text { of fruit } \\
\text { per tree }\end{array}$ & $\begin{array}{c}\text { Yield } \\
\text { per } \\
\text { tree } \\
(\mathrm{kg})\end{array}$ \\
\hline $\mathrm{T}_{1}$ & 9.20 & 8.72 & 222.43 & 2.93 & 9.00 & 8.66 & 98.33 & 282.00 & 62.73 \\
\hline $\mathrm{T}_{2}$ & 8.96 & 8.70 & 218.44 & 3.08 & 8.66 & 8.33 & 99.33 & 272.33 & 59.49 \\
\hline $\mathrm{T}_{3}$ & 7.65 & 7.94 & 207.55 & 3.19 & 7.33 & 7.00 & 100.66 & 229.66 & 47.66 \\
\hline $\mathrm{T}_{4}$ & 7.93 & 8.34 & 214.33 & 3.23 & 8.00 & 7.33 & 101.33 & 261.33 & 56.01 \\
\hline $\mathrm{T}_{5}$ & 8.41 & 8.35 & 220.22 & 3.16 & 8.33 & 8.00 & 102.00 & 265.00 & 58.35 \\
\hline $\mathrm{T}_{6}$ & 6.93 & 7.80 & 204.66 & 3.58 & 7.66 & 6.50 & 105.33 & 221.00 & 45.22 \\
\hline Mean & 8.18 & 8.30 & 214.60 & 3.20 & 8.16 & 7.64 & 101.11 & 255.22 & 54.91 \\
\hline $\begin{array}{l}\text { CD } \\
(p=0.05)\end{array}$ & 0.70 & 0.42 & 4.81 & 0.28 & 0.87 & 0.88 & 1.91 & 10.65 & 2.69 \\
\hline
\end{tabular}


Table 2:-Effect of inorganic and organic fertilizers on biochemical parameters in guava cv. Sardar

\begin{tabular}{|c|c|c|c|c|c|c|c|}
\hline Treatments & $\begin{array}{c}\text { TSS } \\
(\%)\end{array}$ & $\begin{array}{c}\text { Titratable } \\
\text { acidity }(\%)\end{array}$ & $\begin{array}{c}\text { TSS: } \\
\text { acidity }\end{array}$ & $\begin{array}{c}\text { Total } \\
\text { sugars } \\
(\%)\end{array}$ & $\begin{array}{c}\text { Reducing } \\
\text { sugars }(\%)\end{array}$ & $\begin{array}{c}\text { Non- } \\
\text { reducing } \\
(\%)\end{array}$ & $\begin{array}{c}\text { Ascorbic acid } \\
(\mathrm{mg} / 100 \mathrm{~g} \text { of } \\
\text { pulp) }\end{array}$ \\
\hline $\mathrm{T}_{1}$ & 12.19 & 0.54 & 22.51 & 7.97 & 5.43 & 2.54 & 203.91 \\
\hline $\mathrm{T}_{2}$ & 11.24 & 0.58 & 19.80 & 7.63 & 5.35 & 2.28 & 200.41 \\
\hline $\mathrm{T}_{3}$ & 9.63 & 0.62 & 15.64 & 7.41 & 5.23 & 2.18 & 189.58 \\
\hline $\mathrm{T}_{4}$ & 9.14 & 0.56 & 18.33 & 7.22 & 4.98 & 2.24 & 190.41 \\
\hline $\mathrm{T}_{5}$ & 10.25 & 0.56 & 16.43 & 7.55 & 5.28 & 2.27 & 198.33 \\
\hline $\mathrm{T}_{6}$ & 8.80 & 0.63 & 13.96 & 7.13 & 4.67 & 2.46 & 189.33 \\
\hline $\mathrm{Mean}$ & 10.21 & 0.58 & 17.78 & 7.49 & 5.16 & 2.33 & 195.33 \\
\hline $\mathrm{CD}(\mathrm{p}=0.05)$ & 0.37 & $\mathrm{NS}$ & 2.96 & 0.398 & 0.36 & $\mathrm{NS}$ & 10.12 \\
\hline
\end{tabular}

\section{References:-}

1. Ali YM, Iqhal, Shah SZA and Ahmed MJ (2003) Effect of different combinations of nitrogen, phosphorous and farmyard manure on yield and quality of strawberry. Sarh J Agri19: 185-188.

2. Anonymous (2015 a) Package and Practices of Fruits PAU, Ludhiana.

3. AOAC (1990) Official methods of analysis $14^{\text {th }} \mathrm{Ed}$, Association of official Agriculture Chemists, Washington D.C. (USA).

4. Athani SI, Prabhuraj HS, Ustad AI, Swamy GSK, Patil PB and Kotikal YK (2007) Effect of organic and inorganic fertilizers on growth, leaf, major nutrient and chlorophyll content and yield of guava cv. Sardar. ActaHort735: 351-356.

5. Binepal MK, Tiwari R and Kumawat BR (2013) Effect of integrated nutrient management on physico-chemical parameters of guava under Malwa 88 plateau conditions of Madhya Pradesh. Ann Plant Soil Res15: 47-49.

6. Butani AM and Chovatia RS (2013) Effect of chemical fertilizer and vermicompost on biochemical parameters of banana (Musa parasidiaca L.) cv. Grand Naine. The Asian J Hort9: 412-415.

7. Chatterjee R, Jana JC and Paul PK (2013) Vermicompost Substitution influences Shelf Life and Fruit Quality of Tomato (Lycopersiconesculentum Mill.). Columbia International Publishing American J AgrilSci and Tech 1: 69-76.

8. Chhonkar PK (2008) Organic farming and its releveance in India. Organic agriculture Indian Soci Soil SciKalyaniPublisher : 5-33.

9. Dhomane PA and Kadam AS (2013) Influence of different sources of nitrogen on yield and benefit cost of guava (Psidiumguajava L.) cv. Sardar. Scholary J AgrilSci3: 261-263.

10. Dutta P, Kundu S, Bauri FK, Talang H and Majumder D (2014) Effect of bio-fertilizers on physico-chemical qualities and leaf mineral composition of guava frown in alluvial zone of West Bengal. J Crop and Weed10: 268-271.

11. Dutta P, Maji SB and Das BC (2009) Studies on the response of biofertilizers on growth and productivity of guava. Indian J Hort66: 39-42.

12. Dwivedi DH, Lata R, Ram RB and Babu M (2012) Effect of bio-fertilizers and organic manures on yield and quality of 'Red Fleshed'. The Scientific Temper1: 193-198.

13. Katiyar PN, Tripathi VK, Sachan, RK, Singh JP and Chandra R (2012) Integrated nutrient management affects the growth , flowering and fruiting of rejuvenated ber. HortFloora Res. Spectrum 1: 38-41.

14. Khehra S and Bal JS (2016) Influence of combined use of organic, inorganic and biological sources of nutrients on fruit quality in lemon. International J AgriEnvi and Biotech9: 85-88.

15. Kumar N (2012) Productivity, quality and nutrient balance in spring sugarcane under organic and inorganic nutrition. Indian J Agron57: 68-73.

16. Lal G and Sen NL (2001) Effect of N, Zn and Mn fertilization on fruit of guava (PsidiumguajavaL.) cv. Allahabad Safeda. Haryana J HortSci 30: 203-205.

17. Laxmi R, Saravanan PS, Lakshmannaik M (2015) Effect of organic manures and inorganic fertilizers on plant growth, yield, fruit quality and shelf life of tomato (Solanumlycopersicon L.) cv. PKM-1. International J AgrilSci Res2: 7-12.

18. Meena RK, Mahwar LN, Sarolia DK, Saroj PL and Kaushik RA (2013) Improving Yield and Nutrient Status of Rejuvenated Guava Orchard by Integrated Nutrient Management Under Semi-Arid Conditions. Soci Plant Res26: 233-242. 
19. Naik MH and Haribabu R (2007) Feasibility of organic farming in guava (Psidiumgvajava L.). ActaHort734: 365-72.

20. Osman SM, E-Rahman A and AEM (2009) Effect of slow release nitrogen fertilization on growth and fruiting of guava under mid Sinai conditions. Australian J of Basic and Applied Sci3: 4366-4375.

21. Patel DR and Naik AG (2010) Effect of pre-harvest treatment of organic manures and inorganic fertilizers on post harvestshelflife of sapota cv. Kalipatti. Indian J Hort67: 381-386.

22. Pathak PK and Ram RA (2004) Integration of organic farming practices for sustainable production of guava. First International Guava Symposium CHSI Lucknow, India 144 -145.

23. Ram RA, Bhriguvanshi SR, and Pathak RK (2007) Integrated plant nutrient management in Guava (Psidiumguajava L.) cv. Sardar. ActaHort73: 345-350.

24. Sahu PK, Dikshit SN and Sahu V (2014) Review on suitability of biofertilizers in guava cultivation. Recent researches and potential application in India Int J envBiol4: 238-242.

25. Sandhu S and Gill BS (2011) Effect of integrated nutrient management strategies on growth and yield of capegooseberry. J HortSci6: 29-32.

26. Saravanan S, Chander P, Kumar R and Singh J (2013) Influence of different levels of NPK on growth, yield and quality of Phalsa (Grewiasubinaequalis L.) The Asian J Hort2: 433-435.

27. Sharma A, Wali VK, Bakshi P and Jasrotia A (2013) Effect of integrated nutrient management strategies on nutrient status, yield and quality of guava. Indian J Hort70: 333-339.

28. Sharma VK, Tiwari R and Chouhan P (2014) Effect of N, P and their interaction on Physico-Chemical Parameters of Guava (Psidiumguajava) cv. L-49 under Malwa Plateau Conditions. Int J Scientific and Res Publications 11: 2250-3153.

29. Shukla SK, Adak T, Singha A, Kumar K, Singh VK and Singh A (2014) Response of guava trees (Psidiumgvajava) to soil applications of mineral and organic fertilizers and biofertilizers under conditioned of mineral and organic fertilizers and biofertilizers under conditions of low fertile soil. J Hort 22: 105-114.

30. Tassar K, Tiwari JP and Lal S (1989) Effect of different levels of leaf nitrogen on growth, yield and quality of guava (Psidiumguajava L.) Pro Horti20: 213-217.

31. Tucker GA, Seymour GB and Taylor JE (1993) Biochemistry of fruit ripening. Landon: Chapmal\& Hall1: 251.

32. Umar I, Wali VK, Kher R and Jamwal M (2009) Effect of FYM, Urea and Azotobacteron growth, yield and quality of strawberry cv. Chandler. Not Bot HortAgrobatCluj37: 139-143.

33. Verma ML and Chauhan JK (2013) Effect of integrated nutrient application on apple productivity and soil fertility in temperate zone of Himachal Pradesh. Inter J Farm Sci3: 19-27.

34. Yadav IS (1999) An overview of nutrient management in horticultural crops. Indian Hort43: 4. 